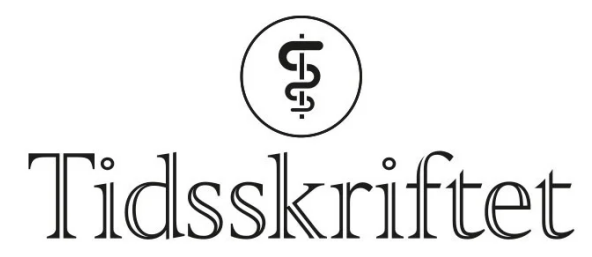

DEN NORSKE LEGEFORENING

\title{
Gode langtidsresultater etter trombolytisk behandling
}

NYHETER

KARSTEN BRUINS SLOT

Email: kbruinsslot@yahoo.no

Oslo universitetssykehus

EIVIND BERGE

Oslo universitetssykehus

Trombolytisk behandling ved hjerneinfarkt gir bedre funksjonsnivå og livskvalitet etter 18 måneder.

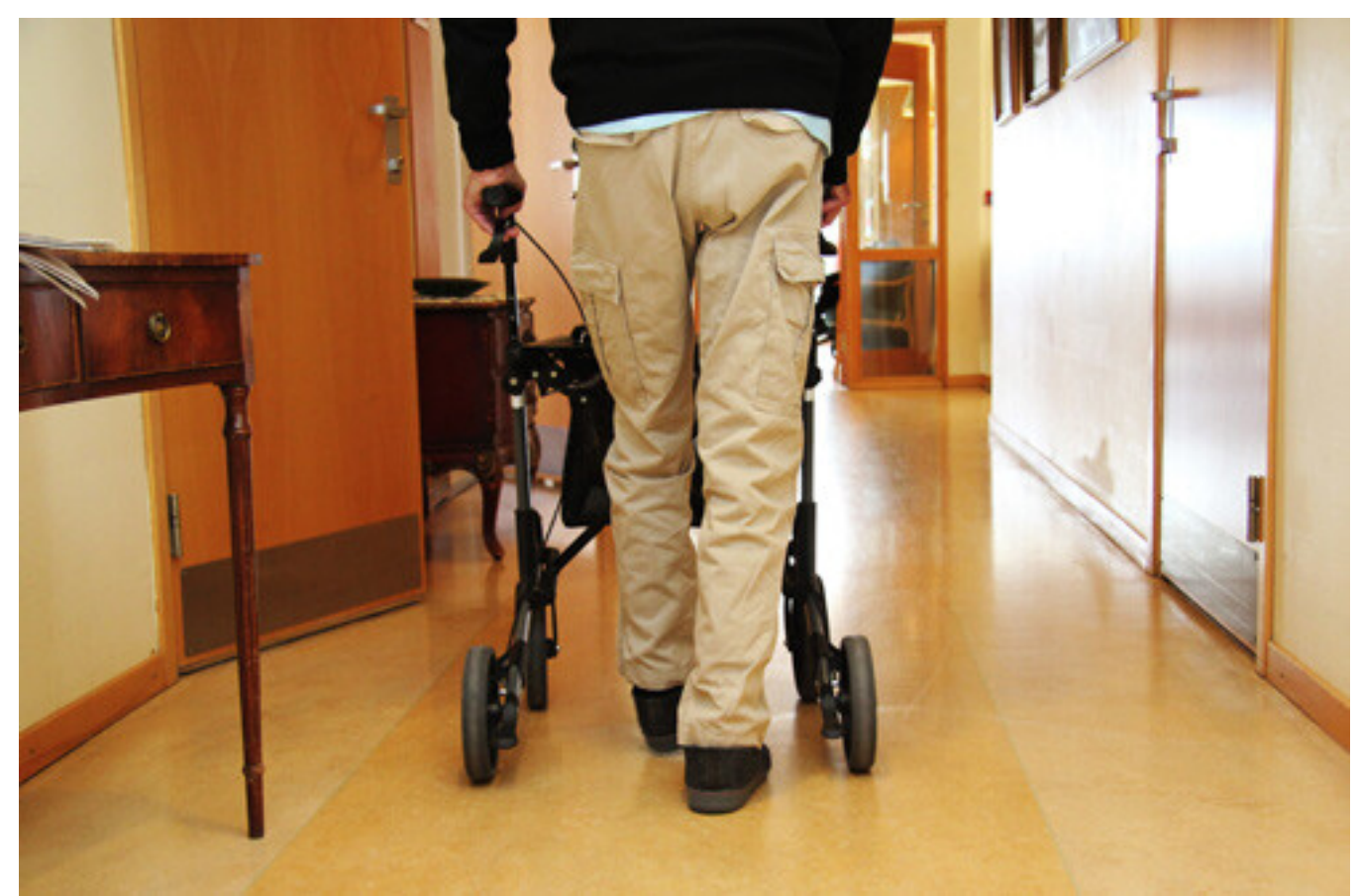

Illustrasjonsfoto NTB scanpix

Behandling med intravenøs rekombinant human vevsplasminogenaktivator (alteplase) brukes nå rutinemessig ved akutt iskemisk hjerneslag. Studien Third International Stroke Trial, som ble publisert i 2012, viste at alteplase er effektiv og trygg behandling også hos 
mange pasienter som ikke tidligere har vært omfattet av godkjenningen for dette preparatet, som for eksempel pasienter over 80 år og pasienter med alvorlige hjerneslag (1).

En oppfølgingsstudie med de samme pasientene viser gode resultater også 18 måneder etter trombolytisk behandling (2 2 ). Pasientene, til sammen over 2300 pasienter, var rekruttert fra Storbritannia, Italia, Sverige og Norge. Funksjonsnivå ble målt ved hjelp av Oxford Handicap Scale, og livskvalitet ble målt med EuroQol-verktøyet. Det var ingen statistisk signifikant forskjell i dødelighet mellom pasienter behandlet med alteplase og kontrollgruppen (34,9\% versus 35,1\%; $p=0,85$ ). Pasienter behandlet med alteplase hadde imidlertid signifikant bedre funksjonsnivå (oddsratio 1,28; $95 \%$ KI 1,03-1,57) og bedre livskvalitet enn pasienter i kontrollgruppen (o,o6 differanse på EuroQol skalaen; p = o,019).

Studien viste altså at trombolytisk behandling med alteplase har viktige, positive effekter på funksjonsnivå og livskvalitet på lang sikt. Denne informasjonen vil være til nytte for klinikere i samtaler med pasienter og pårørende om trombolytisk behandling, og vil være verdifull i helseøkonomiske analyser av denne typen behandling.

\section{LITTERATUR}

1. Sandercock P, Wardlaw JM, Lindley RI et al. The benefits and harms of intravenous thrombolysis with recombinant tissue plasminogen activator within $6 \mathrm{~h}$ of acute ischaemic stroke (the third international stroke trial [IST-3]): a randomised controlled trial. Lancet 2012; 379: 2352-63. [PubMed] [CrossRef]

2. IST-3 collaborative group. Effect of thrombolysis with alteplase within $6 \mathrm{~h}$ of acute ischaemic stroke on long-term outcomes (the third International Stroke Trial [IST-3]): 18-month follow-up of a randomised controlled trial. Lancet Neurol 2013; 12: 768-76. [PubMed] [CrossRef]

Publisert: 15. oktober 2013. Tidsskr Nor Legeforen. DOI: 10.4045/tidsskr.13.1133

(C) Tidsskrift for Den norske legeforening 2023. Lastet ned fra tidsskriftet.no 26. april 2023. 